\title{
A MICROBIOTA DA CARCAÇA E DA CARNE OVINA TRATADA COM ÁCIDO ACÉTICO, EMBALADA A VÁCUO E MATURADA POR 48 DIAS ${ }^{1}$
}

\author{
Elayne C. de VASCONCELOS ${ }^{2}$, Jorge F. F. ZAPATA ${ }^{2, *}$, Evânia A. de FIGUEIREDO², \\ Maria A. A. CASTELO BRANCO², Ângela S. BORGES ${ }^{2}$
}

\section{RESUMO}

Foi avaliada a carga de bactérias mesófilas e coliformes totais e fecais na superficie da carcaça ovina após 12 horas do abate. Posteriormente, a carne foi cortada em fatias de aproximadamente $3 \mathrm{~cm}$ de espessura, imersas por um minuto em ácido acético $1 \%$ ou em água, embaladas individualmente a vácuo e armazenadas a $1^{\circ} \mathrm{C}$. Nos dias $3,13,23,33$ e 48 de maturação as carnes foram analisadas para bactérias mesófilas e psicrotróficas, mofos e leveduras, coliformes totais e fecais, salmonela e clostrídios sulfito-redutores. As contagens de bactérias mesófilas e psicrotróficas foram menores $(p<0,05)$ nas carnes tratadas com ácido acético que nas não tratadas nos dias 13 e 23 e nos dias 3 e 13 de maturação, respectivamente. A contagem de mofos e leveduras foi menor $(\mathrm{p}<0,05)$, nas carnes tratadas em relação às não tratadas, apenas nos dias 13 e 23 de maturação. Após 3 dias de maturação as carnes tratadas mostraram menores $(\mathrm{p}<0,05)$ contagens de coliformes fecais e totais que as não tratadas. As carnes apresentaram presença de salmonela com 3,13 e 23 dias de maturação mais não com 33 e 48. Não foi detectada presença de clostrídios sulfito-redutores durante todo o período de maturação. Pode-se concluir que o tratamento com ácido e as condições de maturação utilizadas neste experimento mantêm baixas contagens de microrganismos mesófilos, psicrotróficos, mofos e leveduras e coliformes por 13 dias. Durante este período, porém, inibição do crescimento de salmonelas somente foi detectada após 33 dias de maturação da carne ovina.

Palavras-chave: carcaça ovina; coliformes fecais; Salmonella; bolores e leveduras; bactérias psicrotróficas.

\section{SUMMARY}

MICROBIAL STATUS OF THE LAMB CARCASS AND THE MEAT TREATED WITH ACETIC ACID, VACUUM PACKAGED AND AGING FOR 48 DAYS. The load of mesophylic, fecal and total coliform microorganisms on lamb carcass was assessed after 12 hours of slaughtering. Meat was then cut into 3 steaks about $3 \mathrm{~cm}$ thick. Steaks were dipped for $1 \mathrm{~min}$ in either $1 \%$ acetic acid solution or plain water, packaged in nylon-polyethylene bags and vacuum-sealed before storing at $1^{\circ} \mathrm{C}$. On days $3,13,23,33$ and 48 of aging meats were analyzed for mesophilic and psycrotrophic bacteria, moulds and yeasts, total and fecal coliform bacteria, Salmonella and sulfitereducing Clostridia. Mesophilic and psycrophilic bacterial counts were lower $(\mathrm{p}<0.05)$ in meats treated with acetic acid than in the untreated meats on days 13 and 23 and on days 3 and 13, respectively. Mould and yeast counts were lower $(p<0.05)$ in meats treated with acetic acid as compared with those untreated only on days 3 and 13 of aging. On day 3 of aging treated meats were lower ( $p<0.05$ ) in both total and fecal coliform counts than untreated meats. Meat samples were found positive for Salmonella with 3, 13 and 23 days of aging and negative with 33 and 48 days of aging. Sulfite-reducing bacteria were absent in meat samples all through the experimental period. It can be concluded that dipping lamb meat pieces in $1 \%$ acetic acid and the aging conditions used in this study can keep low counts of mesophilic, psycrotrophic, and coliform bacteria, as well as mould and yeast for 13 days. Inhibition of Salmonella, however, is observed only after 33 days of aging.

Keywords: lamb carcass; fecal coliforms; Salmonella; moulds and yeasts; psycrotrophic bacteria.

\section{1 - INTRODUÇÃO}

O amaciamento progressivo da carne durante longos períodos de armazenamento em refrigeração é denominado maturação. Esta técnica tem como finalidade, tornar a carne macia e melhorar outras qualidades sensoriais, como por exemplo, o sabor [14]. O processo consiste em manter carcaças ou cortes selecionados em câmaras refrigeradas a $0^{\circ} \mathrm{C}$ por periodos de 7 a 21 dias, dependendo da espécie animal [13].

Contudo, a carne, em virtude de ser um alimento rico em elementos nutritivos, depois de uma permanência relativamente longa em temperaturas de refrigeração, pode permitir o crescimento de microrganismos.

A aplicação de ácidos orgânicos na superficie da carne tem sido empregada na redução de populações de bactérias, e assim estender a vida-de-prateleira e minimizar o risco de doenças transmitidas por alimentos, sem afetar

Recebido para publicação em 01/06/2001. Aceito para publicação em 23/03/2002.

2. Universidade Federal do Ceará-Departamento de TEcnologia de Alimentos. Cx. Postal 12168. CEP 60020-181. Fortaleza. CE. E-mail: zapata@ufc.br

* A quem a correspondência deve ser enviada. a qualidade sensorial da carne [4, 17]. Por razões de solubilidade, sabor e baixa toxicidade, os ácidos orgânicos de cadeia curta, podem ser usados como preservantes ou acidulantes dos alimentos [8].

O presente trabalho teve como objetivo avaliar a microbiota presente na carcaça ovina, bem como verificar o comportamento da microbiota da carne tratada com ácido acético, embalada a vácuo e armazenada por 48 dias a temperatura de $1^{\circ} \mathrm{C}$.

\section{2 - MATERIAL E MÉTODOS}

\section{1 - Descrição do experimento}

Foram utilizados 5 animais ovinos machos castrados do tipo Crioula com idade aproximada de 1 ano, peso vivo médio aproximado de $35 \mathrm{Kg}$, criados em regime semiintensivo, provenientes do interior do estado do Ceará. As operações de abate foram procedidas segundo os métodos recomendados pelo RIISPOA [3], e as carcaças mantidas em câmaras de refrigeração a $0^{\circ} \mathrm{C}$ por 12 horas. Em seguida foram coletadas amostras da superficie dos seguintes locais: paleta, pescoço, peito, lombo, coxão e parede da cavidade abdominal e analisadas para: con- 
tagem de bactérias mesófilas e pesquisa de coliformes totais e fecais. Posteriormente coletaram-se as paletas das carcaças as quais foram serradas, em 5 fatias de peso similar, da porção proximal para a porção distal desse corte, perfazendo total de 50 fatias de carne com osso. As 25 fatias das paletas direitas foram imersas em solução de ácido acético $1 \%$ por $1 \mathrm{~min}$. (tratamento com ácido). As 25 fatias das paletas esquerdas foram imersas por $1 \mathrm{~min}$. em água potável (tratamento controle). Em seguida todas as fatias foram embaladas individualmente a vácuo em filme flexivel de nylon-polietileno, identificadas e armazenadas a $1^{\circ} \mathrm{C}$, durante 48 dias.

Nos dias 3, 13, 23, 33 e 48 de armazenamento, 5 fatias de cada tratamento foram analisadas quanto a contagem de bactérias mesófilas e psicrotróficas, bolores, leveduras e clostridios sulfito-redutores, e feita pesquisa de coliformes totais e fecais bem como de Salmonella, conforme metodologia da APHA [2] e SILVA \& JUNQUEIRA [20].

\section{2 - Análise da carcaça}

A amostragem de cada local da carcaça foi obtida, através de zaragatoa, em 5 pontos diferentes, com o auxílio de um gabarito de $25 \mathrm{~cm}^{2}$ de área, perfazendo um total de $125 \mathrm{~cm}^{2}$ de superficie por local amostrado. As 5 zaragatoas colhidas desta forma foram transferidas para um mesmo tubo contendo $10 \mathrm{~mL}$ de água peptonada. A partir desta suspensão foram efetuadas as diluições para os ensaios. A contagem de bactérias mesófilas foi expressa como UFC $/ \mathrm{cm}^{2}$ e para pesquisa de coliformes totais e fecais como NMP $/ \mathrm{cm}^{2}$, de acordo com APHA [2].

\section{3 - Análise das carnes maturadas}

Após desinfecção superficial das embalagens das carnes com etanol $70 \%$, a embalagem foi aberta para retirada asséptica de uma amostra de $25 \mathrm{~g}$ de carne, a qual foi transferida para saco plástico esterilizado, contendo $225 \mathrm{~mL}$ de água peptonada 0,1\% esterilizada, e homogeneizada por 1 a 2 minutos. Para a preparação da segunda diluição $\left(10^{-2}\right)$, foi transferido assepticamente $1,0 \mathrm{~mL}$ da diluição $10^{-1}$ para $9,0 \mathrm{~mL}$ da solução peptonada. As diluições subseqüentes, até $10^{-6}$ foram obtidas de maneira similar.

Em outro fragmento de carne foi medido o $\mathrm{pH}$ mediante inserção do eletrodo numa incisão feita com bisturi, utilizando-se um medidor digital de pH (Hanna Instruments, modelo 8417, Singapore).

\section{4 - Análise estatística}

Os números referentes a contagens de microrganismos foram transformados em logaritmicos da base 10 para realização da análise estatística. Naqueles relativos à pesquisa de coliformes totais e fecais, em que o NMP foi $<3$ adotou-se o valor 3 .

Para a análise da superficie da carcaça foi utilizado o modelo estatístico em blocos aleatórios, onde cada carcaça foi considerada um bloco [11].

Para verificar o efeito do ácido acético $1 \%$ sobre as carnes ao longo do tempo de maturação utilizou-se a técnica de dados longitudinais [16], onde são consideradas as possiveis correlações entre as observações de uma mesma unidade de amostragem.

Para as comparações múltiplas entre as médias da contagem de bactérias aeróbias mesófilas, bolores e leveduras, da pesquisa de coliformes totais e pesquisa de coliformes fecais e dos valores de $\mathrm{pH}$, foi utilizado o teste de Tukey ao nivel de 5\% de significância. Para as médias de contagem de bactérias psicrotróficas aeróbias ou anaeróbias facultativas foram utilizados contrastes ortogonais, devido à ausência de parcelas dos tratamentos [11].

\section{3 - RESULTADOS E DISCUSSÃO}

\section{1 - Caracterização microbiológica da carcaça ovina}

Não foram detectadas diferenças $(p>0,05)$ entre os diferentes locais analisados na superficie da carcaça (coxão, parede abdominal interna, lombo, peito, paleta e pescoço) quanto a contagem total de bactérias mesófilas, coliformes totais e coliformes fecais (Tabela 1).

TABELA 1. Médias ( $\mathrm{n}=5)$ do número de bactérias $\left(\log \mathrm{UFC} / \mathrm{cm}^{2}\right)$ em diferentes locais da superficie da carcaça ovina, com 12 horas do abate.

\section{Locais da carcaça}

\begin{tabular}{|c|c|c|c|c|c|c|c|}
\hline $\begin{array}{l}\text { Tipos de } \\
\text { bacterias }\end{array}$ & Coxão & $\begin{array}{l}\text { Parede } \\
\text { abdominal }\end{array}$ & Lombo & Peito & Paleta & Pescoço & $\begin{array}{l}\text { Médias na } \\
\text { carcaça* }^{*}\end{array}$ \\
\hline Mesófilas & 2,10 & 1,69 & 1,87 & 1,77 & 2,12 & 1,93 & $1,92 \pm 0,60$ \\
\hline $\begin{array}{l}\text { Coliformes } \\
\text { totais }\end{array}$ & 1,14 & 0,57 & 0,43 & 0,06 & 0,0 & 0,74 & $0,47 \pm 0,89$ \\
\hline $\begin{array}{l}\text { Coliformes } \\
\text { fecais }\end{array}$ & 1,01 & 0,13 & 0,21 & 0,06 & 0,0 & 0,46 & $0,30 \pm 0,94$ \\
\hline
\end{tabular}

Com relação à contagem de bactérias mesófilas, que comumente é empregada para indicar a qualidade sanitária dos alimentos e estimar a vida útil da carne, os valores encontrados variaram de 1,69 na parede abdominal interna a 2,12 na paleta, com média de 1,92logUFC $/ \mathrm{cm}^{2}$ (Tabela 1 ).

De acordo com SILVA [17], o valor médio para a contagem de bactérias mesófilas em carcaças de bovinos é de $1,96 \log \mathrm{UFC} / \mathrm{cm}^{2}$, valor similar a média encontrada neste trabalho, que foi de $1,92 \log \mathrm{UFC} / \mathrm{cm}^{2}$, sugerindo que o abate realizado de acordo com o RIISPOA [3] produz carcaças com boas condições higiênicas.

No que se refere a pesquisa de coliformes totais, os valores encontrados na carcaça ovina variaram de zero na paleta a $1,14 \log \mathrm{UFC} / \mathrm{cm}^{2}$ no coxão, com média de $0,47 \mathrm{logUFC} / \mathrm{cm}^{2}$ para todos os locais (Tabela 1 ).

Com relação aos coliformes fecais os valores encontrados variaram de zero na paleta a $1,01 \log U F C / \mathrm{cm}^{2}$ no coxão, com uma média de $0,30 \log U F C / \mathrm{cm}^{2}$ para todos 
os locais (Tabela 1). A contaminação maior no coxão sugere que a proximidade deste corte à região anal, pode ter sido a causa da contaminação.

Como não foram encontradas diferenças significativas na contagem de bactérias da parede abdominal interna em relação à superficie externa dos outros locais da carcaça analisados, pode-se inferir que não houve perfurações do trato-gastrintestinal durante a evisceração dos animais.

De acordo com ROÇA \& SERRANO [15], as fontes de contaminação da carne são microrganismos da pele, microrganismos do trato-gastrointestinal e o ar atmosférico. As baixas contagens de bactérias obtidas na superficie das carcaças neste estudo após 12 horas de armazenamento frigorífico (Tabela 1) sugerem também que a contaminação através do ar não foi significativa.

\section{2 - Evolução da microbiota da carne ovina durante a maturação.}

Foi detectada interação $(p<0,05)$ entre tratamento e tempo de maturação para contagem padrão em placas de bactérias mesófilas. Com 3 dias de armazenagem a contagem de bactérias mesófilas não apresentou diferença ( $p>0,05)$, entre as carnes tratadas e não tratadas (Figura 1). Comportamento similar foi encontrado por outros pesquisadores $[7,10]$, no primeiro dia de estocagem, ao estudarem a microbiota da carne bovina tratada com ácidos acético e láctico. Com 13 e 23 dias de armazenamento, foram observados niveis menores $(p<0,05)$ na contagem de bactérias mesófilas, nas amostras tratadas em relação às não tratadas. Esta diferença foi de aproximadamente 2 ciclos logaritmicos aos 13 dias e de 3 ciclos logarítmicos com 23 dias de maturação (Figura 1).

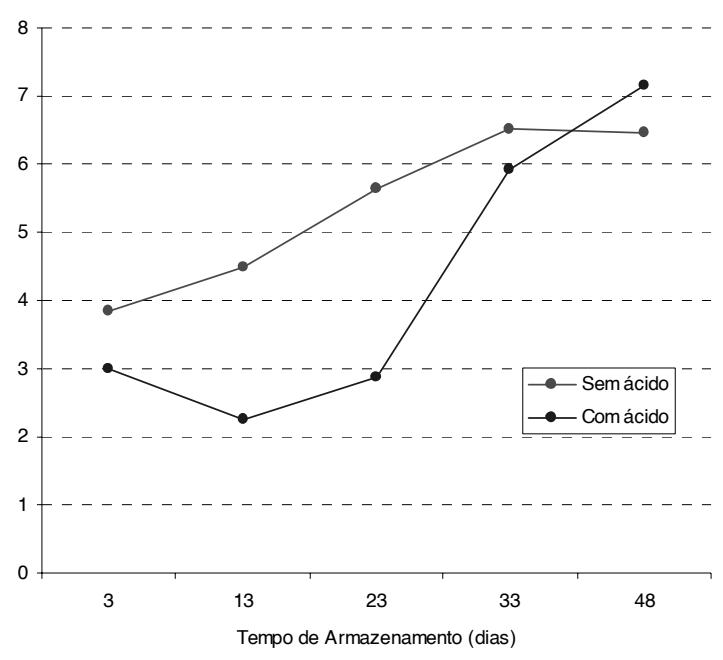

FIGURA 1. Contagem padrão em placa de bactérias mesófilas aeróbicas ou anaeróbicas facultativas $(\log \mathrm{UFC} / \mathrm{g})$, na carne de paleta ovina, submetida ou não a tratamento com ácido acético $1 \%$ e armazenada a $1^{\circ} \mathrm{C}$, por 48 dias.

Desta forma, o efeito do ácido acético $1 \%$ foi eficiente na redução da microbiota mesófila, somente até os 23 dias de armazenamento da carne. Similarmente, outros autores $[7,9,10]$, têm evidenciado que o efeito inibitório desses ácidos decresce com o tempo de estocagem.

FU, SEBRANEK, MURRANO [6], estudando a qualidade microbiológica da carne de lombo de porco, proveniente de carcaças borrifadas com soluções 1,5\% de ácido acético, ácido cítrico e acido láctico, embalada a vácuo e armazenada entre 0 e $2^{\circ} \mathrm{C}$ por 42 dias, verificaram que o ácido acético e cítrico mostraram inicialmente um decréscimo na contagem padrão em placa. Este efeito, porém, não continuou depois de 14 dias de estocagem das amostras embaladas a vácuo e, depois de 42 dias, a contagem padrão em placas no lombo suino foi superior a 6 ciclos logarítmicos, condição considerada inaceitável na carne. No presente estudo com carne ovina contagens acima de 6 ciclos logarítmicos somente foram encontradas com pouco mais de 33 dias para as tratadas e, com aproximadamente 28 nas não tratadas (Figura 1), provavelmente devido ao fato desta carne ter sido tratada com ácido imediatamente antes da embalagem, em contraposição com a carne suina [6] onde o tratamento com ácido foi feito na carcaça.

Para a contagem de bactérias psicrotróficas, houve também interação $(\mathrm{p}<0,05)$ entre tratamento e tempo de maturação. Nos dias 3 e 13 de armazenamento observou-se menores $(p<0,05)$ niveis destas bactérias $(1,3$ e 3,5 ciclos logarítmicos, respectivamente) nas carnes tratadas com ácido acético 1\%. Entretanto nos dias 23, 33 e 48 de estocagem, não foram verificadas diferenças $(\mathrm{p}>0,05)$ entre os tratamentos (Figura 2), sugerindo um efeito mais notório do ácido sobre as bactérias psicrotróficas apenas nos primeiros 13 dias de armazenamento.

Outros autores [7, 18, 19], trabalhando com sanitização de carne bovina com ácidos orgânicos, observaram que em média nos primeiros dois dias de estocagem a contagem de bactérias psicrotróficas foi similar nas amostras tratadas e não tratadas.

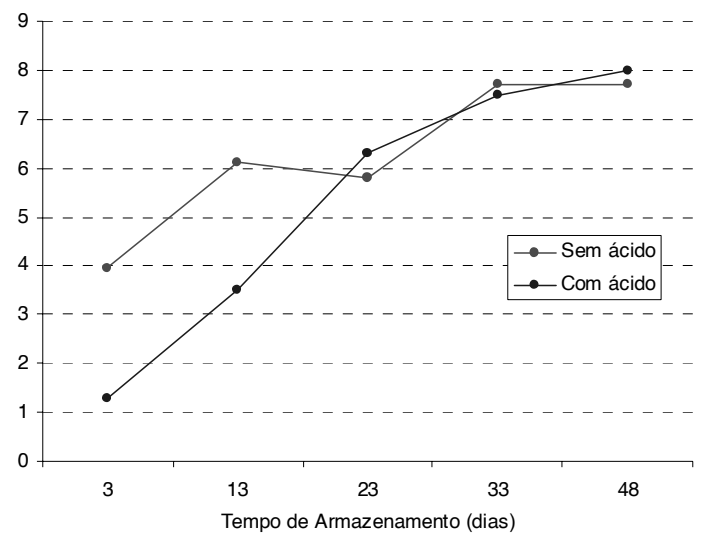

FIGURA 2. Contagem padrão em placa de bactérias psicrotróficas aeróbicas ou anaeróbicas facultativas (logUFC/ g), na carne de paleta ovina, submetida ou não a tratamento com ácido acético $1 \%$ e armazenada a $1^{\circ} \mathrm{C}$, por 48 dias.

Contudo, os resultados deste estudo (Figura 2), estão de acordo com os de SILVA \& BERAQUET [19] e 
DICKSON \& SIRAGUSA [5], que em média de 15 dias de estocagem, não observaram mais o efeito do tratamento nas carnes tratadas com ácidos láctico e acético.

Apesar de ter sido observadas baixas contagens de bactérias psicrotróficas nas carnes tratadas até o dia 13 de armazenamento, com 23 dias a carne tratada apresentou contagem superior à carne não tratada (Figura 2). Este comportamento poderia ser atribuido a processos tais como, competição ou depleção de nutrientes entre microrganismos [8]. Segundo outros autores [19], este aumento no número de microrganismos psicrotróficos viáveis na carne submetida aos tratamentos pode ser atribuído a perda da eficiência dos ácidos utilizados na sanitização.

A ação do ácido acético 1\% sobre as bactérias mesófilas foi verificada até os 23 dias de estocagem (Figura 1). Com relação às bactérias psicrotróficas houve uma redução da carga somente no período inicial (Figura 2). Isto sugere que em condições de refrigeração as bactérias mesófilas não crescem bem, sendo as psicrotróficas as principais causadoras da gradual deterioração da carne.

As carnes tratadas apresentaram contagens menores $(\mathrm{p}<0,05)$ de bolores e leveduras que as não tratadas (Figura 3). Foi observada uma redução de aproximadamente 0,5 ciclo logaritmico na contagem desses microrganismos em relação às amostras não tratadas, independente do tempo de estocagem.

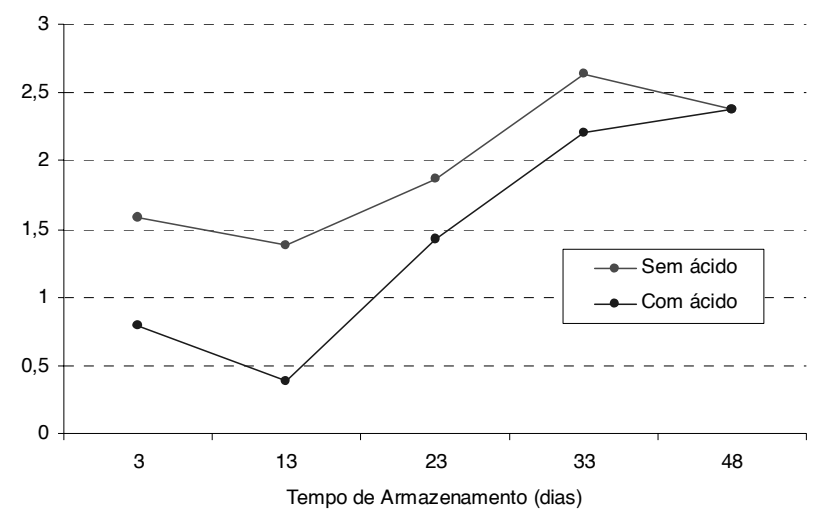

FIGURA 3. Contagem padrão em placa de bolores e leveduras $(\operatorname{logUFC} / \mathrm{g})$, na carne de paleta ovina, submetida ou não a tratamento com ácido acético $1 \%$ e armazenada a $1^{\circ} \mathrm{C}$, por 48 dias.

O presente estudo sugere que o crescimento observado para bolores e leveduras se refere principalmente ao das leveduras, devido ao fato dos bolores serem aeróbicos estritos e as carnes terem sido acondicionadas em embalagem a vácuo.

No dia 13, o valor médio da contagem de bolores e leveduras na carne ovina foi menor $(\mathrm{p}<0,05)$ do que nos dias 33 e 48 (Figura 3).

SILVA \& BERAQUET [19] trabalhando com ácidos orgânicos na sanitização da carne bovina, observaram uma sensivel redução de bolores e leveduras nos dias 7 e 9 de armazenamento nas amostras tratadas, compor- tamento similar ao encontrado neste estudo no dia 13 de armazenamento (Figura 3) .

Os dados da pesquisa de coliformes totais indicaram uma interação $(\mathrm{p}<0,05)$ entre tratamento com ácido e tempo de maturação (Figura 4).

No dia 3 de armazenamento as amostras tratadas com ácido acético 1\% apresentaram contagens menores $(p<0,05)$ de coliformes totais que as não tratadas. Esta redução foi de aproximadamente 1 ciclo logaritmico (Figura 4). Entretanto, ALMEIDA, SILVA, ALMEIDA [1], afirmam que o uso de soluções diluídas de ácido acético na carcaça de cordeiro pode reduzir em 2,0 ciclos logarítmicos o número de bactérias coliformes na carne embalada a vácuo, estendendo sua vida-de-prateleira de uma para quatro semanas.

Foi verificada uma redução $(p<0,05)$ de coliformes fecais nas carnes tratadas com ácido acético $1 \%$ em relação às não tratadas (Figura 5), independente do tempo de maturação. Diferentemente, no trabalho de FU, SEBRANEK, MURRANO [6], onde também foi detectada uma redução na contagem de coliformes fecais na carne suína, observou-se que o ácido acético foi eficiente inibindo os coliformes fecais apenas no dia zero de estocagem.

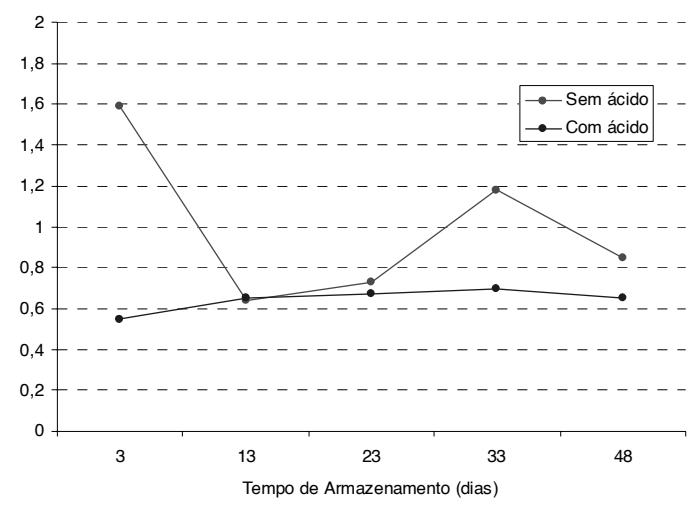

FIGURA 4. Pesquisa de coliformes totais (logNMP/g), na carne de paleta ovina, submetida ou não a tratamento com ácido acético $1 \%$ e armazenada a $1^{\circ} \mathrm{C}$, por 48 dias.

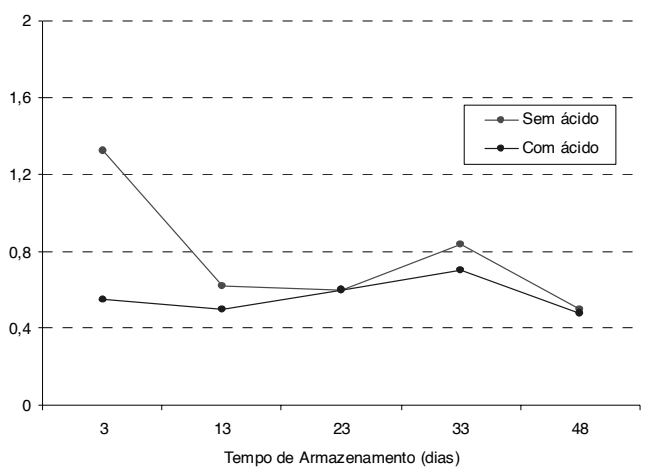

FIGURA 5. Pesquisa de coliformes fecais (logNMP/g), na carne da paleta ovina, submetida ou não a tratamento com ácido acético $1 \%$ e armazenada a $1^{\circ} \mathrm{C}$, por 48 dias. 
PUGA, CONTRERAS, TURNBULL [14], avaliando o efeito do amaciamento da carne bovina embalada a vácuo, por 9 e 14 dias, observaram contagens de 4,0 $\log \mathrm{UFC} / \mathrm{g}$ e <3,0 logUFC/g para coliformes fecais, respectivamente, valores esses superiores aos encontrados neste estudo com carne ovina.

Não foi evidenciado crescimento de bactérias sulfitoredutoras em nenhuma das amostras, independente do tratamento com ácido e do tempo de maturação da carne, sugerindo a ausência deste tipo de bactérias na carne ovina visto que condições como $\mathrm{pH}$ e armazenamento anaeróbico poderiam favorecer o crescimento desses microrganismos.

Para a pesquisa de Salmonella, obteve-se resultados positivos (Figura 6) no início da maturação (3, 13 e 23 dias de armazenamento), nas carnes tratadas e não tratadas com ácido acético $1 \%$ e ausência do dia 33 ao dia 48 de maturação. Pode-se sugerir que a ausência de Salmonella (Figura 6) observada aos 33 e 48 dias de estocagem, possa ser devido ao fato desta bactéria não competir bem com bactérias produtoras de ácido-láctico. A faixa de $\mathrm{pH}$ da carne encontrada neste estudo foi de 6,05 a 6,47 (Figura 7), sendo que existem estudos [12] em que se reporta que as Salmonellas crescem numa faixa de $\mathrm{pH}$ de 4,5 a 9,0, tendo um $\mathrm{pH}$ ótimo de 6,5 a 7,5.

Apesar de se esperar uma pequena e temporária redução do $\mathrm{pH}$ da carne, não foi observada diferença $(p>0,05)$ no valor deste parâmetro nas amostras tratadas e não tratadas, independente do tempo de maturação. Isto pode ter sido devido ao fato das medições terem sido feitas na carne numa profundidade de aproximadamente $1 \mathrm{~cm}$ da superficie que teve contato direto com o ácido. Também pode ter contribuído o efeito neutralizador das proteinas musculares e de reações autoliticas durante o armazenamento da carne que ocasionam a formação de compostos básicos que aumentam o pH [19].

Os valores de $\mathrm{pH}$ encontrados neste trabalho tiveram pouca variação. Contudo foram detectados valores de $\mathrm{pH}$ maiores $(\mathrm{p}<0,05)$ nos tempos 13 e 48 dias e em relação aos tempos 3, 23 e 33 dias de armazenamento das carnes (Figura 7).

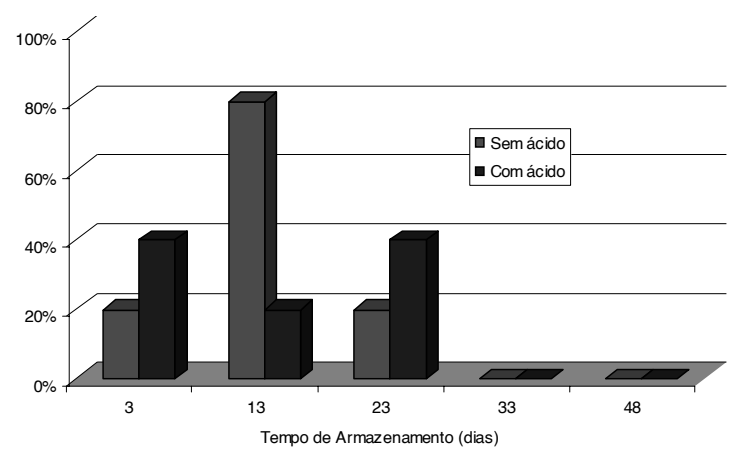

FIGURA 6. Pesquisa de Salmonella na carne de paleta ovina, submetida ou não a tratamento com ácido acético $1 \%$ e armazenada a $1^{\circ} \mathrm{C}$, por 48 dias.
SILVA \& BERAQUET [19], estudando o efeito da sanitização com ácidos orgânicos, sobre a redução da contaminação inicial de carne bovina, observaram que imediatamente após a aspersão das soluções, o pH superficial dos músculos foi reduzido significativamente, situando-se na faixa de 4,0 a 4,2; contudo após um dia de armazenagem, já não se observou diferença $(p>0,05)$ nos valores de $\mathrm{pH}$ da superfície dos músculos submetidos aos tratamentos e dos do controle. Similarmente, SILVA [17], trabalhando com sanitização de carne bovina com misturas de ácidos orgânicos, verificou que os valores de $\mathrm{pH}$ foram baixos logo depois dos tratamentos, e atingiram valores maiores, praticamente constantes e iguais aos observados no controle, até o $9^{\circ}$ dia de armazenamento.

Os valores mais elevados de $\mathrm{pH}$ da carne ovina encontrados neste estudo se devem, provavelmente, ao fato das medições terem sido praticadas com eletrodo de imersão.

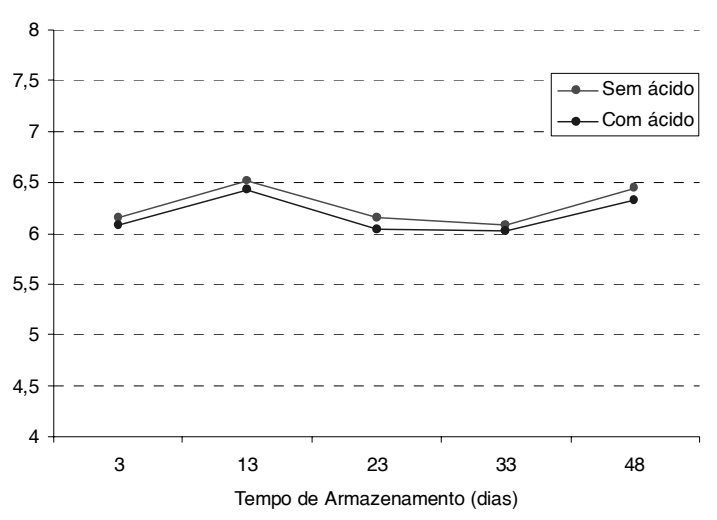

FIGURA 7. Médias dos valores de $\mathrm{pH}$, na carne de paleta ovina, submetida ou não a tratamento com ácido acético $1 \%$ e armazenada a $1^{\circ} \mathrm{C}$, por 48 dias.

\section{4 - CONCLUSÕES}

- O tratamento com ácido acético $1 \%$, seguido de embalagem a vácuo e temperatura de armazenamento de $1^{\circ} \mathrm{C}$ não afeta $\circ \mathrm{pH}$, inibe o crescimento de bactérias mesófilas, bolores e leveduras por duas semanas e o de bactérias do grupo coliformes por 6 semanas, na carne ovina maturada.

- O ácido acético 1\% não é eficiente para inibir o crescimento de bactérias do gênero Salmonella na carne ovina.

\section{5 - REFERÊNCIAS BIBLIOGRÁFICAS}

[1] ALMEIDA, P.F., SILVA, E.N., ALMEIDA, R.C.C. Contaminação e disseminação de carcaça de frangos em abatedouros. Higiene Alimentar, São Paulo, v. 7, n. 27, p. 12-17, 1993.

[2] APHA American Public Health Association. Compendium of Methods for the Microbiological Examination of Foods. 30th ed., Marvinil, Washington, D.C. 1992. 1208p4p. 
[3] BRASIL, MINISTÉRIO DA AGRICULTURA. Regulamento da Inspeção Industrial e Sanitária de Produtos de Origem Animal. Ministério da Agricultura, Brasília, 1997.

[4] DELMORE, G. L. R., SOFOS, J. N., SCHMITDT, G. R. et al. Decontamination of inoculated beef with sequential spraying treatments. Journal of Food Science, Chicago, v. 63, n. 5, p. 890-893, set./out. 1998.

[5] DICKSON, J. S., SIRAGUSA, G. R. Survival of Salmonella typhimurium, Escherichia coli 0157: H7 and Listeria monocytogenes during storage on beef sanitized with organic acids. Journal of Food Safety, Trumbull, v. 14, p. 313-327, 1994.

[6] FU, A. H., SEBRANEK, J. G., MURRANO, E. A. Microbial and Quality Characteristics of Pork Cuts from Carcasses Treated with Sanitizing spray. Journal of Food Science, Chicago, v. 59, n. 2, p. 306-309, mar./abr. 1994.

[7] GODDARD, B. L., MIKEL, W. B., CONNER, D. E. et al. Use of Organic acids to Improve the Chemical, Physical, and Microbial attributes of beef strip loins Stored at $-1^{\circ} \mathrm{C}$ for 112 days. Journal of Food Protection, Des Moines, Iowa, v. 59, n. 8, p. 849-853, 1996.

[8] ICMSF. International Commision on Microbiological Specifications for Foods (ICMSF). Microbial ecology of foods. 1: Factors affecting life and death of microorganisms. Academic Press. London. 1980. 259p.

[9] KIM. C.R., KIM, K.H., CHUNG, H.J. et al. Microbiological and sensory qualities of refrigerated chicken breasts treated with organic acids. In: 1999 IFTANNUAL MEETING, 1999, Chicago. Anais .... Chicago: 1999. p.83C- 17 .

[10] KOTULA, K. L. \& THELAPPURATE, R. Microbiological and sensory attributes of retail cuts of beef treated with acetic and lactic acid solutions. Journal of Food Protection, Des Moines, Iowa, v. 57, n. 8. p. 665-670, 1994.

[11] MONTGOMERY, D.C. Design and analysis of experiments, $3^{\text {rd }}$ ed. John Wiley \& Sons, New York, 1991. 649p.

[12] PINTO, P.S.A. Aspectos sanitários da salmonelose como zoonose. Higiene Alimentar, São Paulo, v. 14, n. 73, p. 39-43, jun. 2000.
[13] PRICE, J. F. \& SCHWEIGERT, B. S. The science of meat and meat products. 2 rd. W.H.Freemam and company. San Francisco, 1971. 660p.

[14] PUGA, D. M. U., CONTRERAS, C. J. C., TURNBULL, M. R. Avaliação do amaciamento da carne bovina de dianteiro (Tríceps brachii) pelos métodos de maturação, estimulação elétrica, injeção de ácidos e tenderização mecânica. Ciênc. Tecnol. Aliment., Campinas, v. 19, n. 1, p. 88-96, jan./abr. 1999.

[15] ROÇA, R. de O. \& SERRANO, A. de M. Abate de bovinos: Alteraçōes microbianas da carcaça. Higiene Alimentar, São Paulo, v. 9, n. 35, p. 8-13, jan./fev. 1995.

[16] SINGER, J.M., ANDRADE, D.F. Análise de dados longitudinais. In: VII SIMPÓSIO NACIONAL DE PROBABILIDADE E ESTATÍSTICA, 1996, Campinas, SP. Anais... Campinas: ABE, 1986. 108p.

[17] SILVA, J. A. Sanitização da carne com ácidos orgânicos. Parte I. Higiene Alimentar, São Paulo, v. 13, n. 60, p. 5562, mar. 1999.

[18] SILVA, J. A. Sanitização da carne com ácidos orgânicos. Parte II. Higiene Alimentar, São Paulo, v. 13, n. 62, p. 37-43, jun. 1999.

[19] SILVA, J. A., BERAQUET, N. J. Redução da contaminação inicial de carne bovina pela sanitização com ácidos orgânicos. B. CEPPA. Curitiba, v. 15, n. 2, p. 127-142. jul./dez. 1997.

[20] SILVA, N., JUNQUEIRA, U. C. A. Métodos de análise microbiológica de alimentos. Campinas: Instituto de Tecnologia de Alimentos, 1995. 229p. (Manual técnico, no 14).

\section{6 - AGRADECIMENTOS}

À CAPES (Coordenação de Aperfeiçoamento de Pessoal de Nivel Superior) pala concessão de Bolsa de Mestrado e ao CNPq (Conselho Nacional de Desenvolvimento Científico e Tecnológico) pelo auxílio financeiro à pesquisa (Proc. 520624/98-0). 